\title{
Practical considerations concerning the use of stem cells for peripheral nerve repair
}

\author{
Sarah Walsh, B.Sc., ${ }^{1}$ and Rajiv Midha, M.D., M.Sc., F.R.C.S.C. ${ }^{1,2}$ \\ ${ }^{1}$ Hotchkiss Brain Institute, and ${ }^{2}$ Department of Clinical Neurosciences, University of Calgary, Alberta
}

\begin{abstract}
In this review the authors intend to demonstrate the need for supplementing conventional repair of the injured nerve with alternative therapies, namely transplantation of stem or progenitor cells. Although peripheral nerves do exhibit the potential to regenerate axons and reinnervate the end organ, outcome following severe nerve injury, even after repair, remains relatively poor. This is likely because of the extensive injury zone that prevents axon outgrowth. Even if outgrowth does occur, a relatively slow growth rate of regeneration results in prolonged denervation of the distal nerve. Whereas denervated Schwann cells (SCs) are key players in the early regenerative success of peripheral nerves, protracted loss of axonal contact renders Schwann cells unreceptive for axonal regeneration. Given that denervated Schwann cells appear to become effete, one logical approach is to support the distal denervated nerve environment by replacing host cells with those derived exogenously. A number of different sources of stem/precursor cells are being explored for their potential application in the scenario of peripheral nerve injury. The most promising candidate, transplant cells are derived from easily accessible sources such as the skin, bone marrow, or adipose tissue, all of which have demonstrated the capacity to differentiate into Schwann cell-like cells. Although recent studies have shown that stem cells can act as promising and beneficial adjuncts to nerve repair, considerable optimization of these therapies will be required for their potential to be realized in a clinical setting. The authors investigate the relevance of the delivery method (both the number and differentiation state of cells) on experimental outcomes, and seek to clarify whether stem cells must survive and differentiate in the injured nerve to convey a therapeutic effect. As our laboratory uses skin-derived precursor cells (SKPCs) in various nerve injury paradigms, we relate our findings on cell fate to other published studies to demonstrate the need to quantify stem cell survival and differentiation for future studies. (DOI: 10.3171/FOC.2009.26.2.E2)
\end{abstract}

\section{Key Words - denervation - nerve injury • nerve regeneration • Schwann cell $\quad$ skin-derived precursor cell}

\section{Clinical Problem: Poor Outcome From Nerve Injuries Despite Repair}

I NJURIES of the peripheral nerves are common and debilitating, affecting $2.8 \%$ of trauma patients ${ }^{44}$ and resulting in considerable long-term disability. ${ }^{27}$ The assumption has been that peripheral nerve injuries recover, given the observation of spontaneous axonal regeneration following insult. While this capacity for regeneration is higher than that of the central nervous system, complete recovery is fairly infrequent, misdirected, or associated with debilitating neuropathic pain. ${ }^{57}$ In fact, satisfactory results only tend to occur following relatively minor injuries, such as neurapraxia or axonotmesis. ${ }^{21}$ Nerve transection is associated with notoriously poor outgrowth compared with other injuries, particularly when the distance between injury and target is long.

Abbreviations used in this paper: $\mathrm{BMSC}=$ bone marrow stromal cell; GFAP = glial fibrillary acidic protein; GFP = green fluorescent protein; $\mathrm{MBP}=$ myelin basic protein; $\mathrm{SKPC}=$ skin-derived precursor cell.
Poor outcome from peripheral nerve injury is especially evident when repair is performed after a temporal delay, ${ }^{31,51,56}$ occurring frequently in clinical practice. Due to the nature of most nerve injuries where the nerve is left in physical continuity, the propensity for spontaneous recovery is not immediately known. ${ }^{37}$ As such, surgical repair is significantly delayed in a great number of cases. Even patients undergoing immediate nerve repair are subject to a lengthy denervation of the distal nerve as a result of the low rate of regeneration $(\sim 1 \mathrm{~mm} /$ day in humans $\left.^{58}\right)$ and the long regeneration distances required to reach the end organ.

Elongation of regenerating axons is initially supported by resident Schwann cells that undergo a phenotypic change from myelinating to growth supportive following initial denervation. ${ }^{38,52}$ This switch in Schwann cell phenotype is associated with up-regulation of several growth associated genes including neurotrophic factors, p75 NTR, GFAP, GAP-43, netrin-1, and key transcription factors. ${ }^{14,38,52}$ Proliferating Schwann cells are a rich source of neurotrophins, cell adhesion molecules, and 
cytokines that support axonal regeneration and recruit further cells into the injury site. ${ }^{14,63,68}$ Unless axonal contact is reestablished in a timely fashion, however, this growth supportive environment is not maintained. ${ }^{49,62,72}$ Denervated Schwann cells progressively lose their ability to express regeneration-assisting genes ${ }^{32,74}$ and in effect become "turned off." 14 As the capacity of the denervated distal nerve to support axonal regeneration is highly dependent on proliferating Schwann cells within the basal lamina tubes ${ }^{7}$ that guide elongating axons to their denervated target,$^{50}$ this loss of vitality and functionality in distal Schwann cells directly translates to poor muscle reinnervation outcomes. ${ }^{15}$

\section{Role of Alternative Repair Strategies}

Although placement of interposed autologous nerve grafts offers a cell-rich material through which axons can regenerate, their use is not ideal because of donor site morbidity, lack of donor tissue availability, and nonspecific regeneration. ${ }^{5,43}$ Recent advances in tissue engineering have introduced synthetic nerve guide conduits that are capable of bridging small defects in peripheral nerves (up to $\sim 3 \mathrm{~cm}$ in humans), but their relatively inert microenvironment reduces their value for larger or more chronic injuries. ${ }^{3,71}$ It appears that combined approaches with cells ${ }^{29}$ or trophic factors ${ }^{28}$ within synthetic tubes may extend their functionality. Indeed, delivery of Schwann cells in a variety of repair paradigms has been successful in promoting regeneration and remyelination of the injured spinal cord ${ }^{48,61}$ and peripheral nerve. ${ }^{16}$ However, human Schwann cells must be derived from invasive nerve biopsies in sufficient numbers for regeneration and are only available after a lengthy expansion time in vitro. ${ }^{17}$ Therefore, several groups have turned their attention to identifying more accessible sources of Schwann cell-like cells for transplant therapies.

\section{Sources of Stem Cells for Peripheral Nerve Repair}

Emphasis has been placed on exploring stem or progenitor cells that are easily accessible, rapidly expandable in culture, capable of survival and integration within the host tissue, and amenable to stable transfection and expression of exogenous genes. ${ }^{4}$ Table 1 summarizes many of the studies to date. Embryonic neural stem cells or cell lines have been used to repair nerve injuries with demonstration of regenerative success ${ }^{2,18,42}$ but suffer the drawback of being somewhat difficult to obtain. On the other hand, adult stem cells have the advantage of being available from relatively noninvasive, autologous harvest methods, and are likely the most promising choice for the majority of clinical nerve injuries. Bone marrow stromal cells have attracted the attention of several groups interested in cellular strategies to supplement nerve repair. ${ }^{10,12,20,26,54,64,70,75}$ These mesenchymal stem cells are harvested from the long bones, and when placed in culture medium containing the appropriate cytokine cocktail, ${ }^{26}$ transdifferentiate into an adherent Schwann cell-like phenotype expressing S100 protein, GFAP, and p75. 12,64 They have been used with artificial conduits and acellular grafts, where they have contributed to improved electrophysiological, morphometric, and/or behavioral recovery outcomes versus vehicle controls. Although their potential to produce functional myelin in vivo has been questioned, ${ }^{69}$ others have shown that these BMSC-derived Schwann cells are at very least capable of myelinating cultured PC12 cells in vitro, ${ }^{26}$ further highlighting their therapeutic potential.

More recently, even less invasive sources of stem cells have been discovered. Adipose tissue has been identified as a niche for a multipotent stem cell with a comparable phenotypic profile to the bone marrow stromal cells, and it appears to differentiate into a myelinating Schwann cell phenotype in vitro given the appropriate medium formulation known to promote transdifferentiation of BMSCs. ${ }^{30,73}$ Further studies will be required to assess whether they can also translate this advantage to the injured peripheral nerve.

The skin and its associated structures pose another easily accessible source of stem cells. A large population of neural crest stem cells has been found in the bulge area of hair and whisker follicles that can differentiate into neurons, smooth muscle cells, Schwann cells, and melanocytes. ${ }^{55}$ Cells isolated from the vibrissal follicle bulge area have been used to repair a gap created in rodent peripheral nerve, where they differentiate into Schwann cell-like cells and improve recovery. Similarly, when stem cells derived from skin were transplanted into artificial nerve guidance tubes bridging a 16-mm gap in rodent sciatic nerve, there was promising improvement in behavioral, electrophysiological, and morphometric parameters measured over vehicle control. ${ }^{34}$ It should be noted that cells in this study were used naive and only a small proportion differentiated into Schwann cells in the in vivo environment. The skin dermis contains neural crest-related precursor cells (termed SKPCs) that can differentiate into neural crest cell types in vitro when supplied the appropriate cues, including those with characteristics of peripheral neurons and Schwann cells. . $^{13,36,66,67}$ The SKPCs respond to neuregulins in vitro to generate Schwann cells, highlighting their potential to serve as transplantable cells for nerve injury models (where neuregulins are liberated from cells within the nerve). ${ }^{9,33}$ The SKPCs that are Schwann cell-like in their apparent differentiation (SKPC-Schwann cell), survive and associate with axons within both normal mouse sciatic nerve and distal to crush, where they express a myelinating phenotype. ${ }^{38}$ Indeed, SKPCs appear to generate functional Schwann cells as they myelinate both sensory neurons in dorsal root ganglion cocultures in vitro and dysmyelinating shiverer mouse ${ }^{42}$ nerve axons in vivo. ${ }^{38}$

\section{Considerations for Optimizing Stem Cell Therapy for Peripheral Nerve Repair}

\section{Number and Method of Stem Cell Delivery}

Although often not reported, the number of cells delivered to nerve injuries in animal models varies considerably between studies. While some have used as few as $4 \times 10^{3}$ cells, $^{2}$ others have transplanted $2 \times 10^{7}$ cells, ${ }^{20}$ but there has often been little explanation for the selection of 


\section{The use of stem cells for peripheral nerve repair}

TABLE 1: Selected studies of transplanted stem cells for peripheral nerve repair ${ }^{*}$

\begin{tabular}{|c|c|c|c|c|c|c|c|c|}
\hline $\begin{array}{l}\text { Cell Source/ } \\
\text { Type }\end{array}$ & $\begin{array}{l}\text { Authors } \\
\& \text { Year }\end{array}$ & $\begin{array}{l}\text { Donor/ } \\
\text { Host } \\
\text { Animal }\end{array}$ & $\begin{array}{l}\text { No. of } \\
\text { Cells } \\
\text { Injected }\end{array}$ & Delivery Method & $\begin{array}{l}\text { Cell Sur- } \\
\text { vival Time }\end{array}$ & $\%$ Survival & Phenotype & $\begin{array}{c}\text { Regenerative } \\
\text { Advantage Con- } \\
\text { ferred Over Vehicle }\end{array}$ \\
\hline \multirow{7}{*}{$\begin{array}{l}\text { bone mar- } \\
\text { row aspirate/ } \\
\text { mesenchymal } \\
\text { stem cell }\end{array}$} & $\begin{array}{l}\text { Hu et al., } \\
2007\end{array}$ & $\begin{array}{l}\text { Rhesus } \\
\text { monkey }\end{array}$ & $2 \times 10^{7}$ & $\begin{array}{l}\text { proximal/distal side } \\
\text { of acellular allograft }\end{array}$ & ND & ND & ND & $\begin{array}{l}\uparrow \text { no. of } \mathrm{NF}+\text { axons, } \\
\text { improved CMAP } \\
\text { amp/latency }\end{array}$ \\
\hline & $\begin{array}{l}\text { Keilhoff } \\
\text { et al., } \\
2006^{25}\end{array}$ & Wistar rat & $\begin{array}{l}2 \times 10^{6} / \\
\mathrm{ml}\end{array}$ & $\begin{array}{l}\text { devitalized muscle } \\
\text { conduits }\end{array}$ & $\geq 6$ wks & ND & $\begin{array}{l}\text { MBP+, bipolar morphol- } \\
\text { ogy in predifferentiated } \\
\text { cells only }\end{array}$ & $\begin{array}{l}\uparrow \text { no. of myelinated } \\
\text { fibers; faster return } \\
\text { of thermosensitivity }\end{array}$ \\
\hline & $\begin{array}{l}\text { Chen et } \\
\text { al., } 2007\end{array}$ & $\begin{array}{l}\text { Sprague- } \\
\text { Dawley rat }\end{array}$ & $10^{6}$ cells & $\begin{array}{l}\text { in gelatin w/in } \\
\text { lumen of silicone } \\
\text { tube; } 15-\mathrm{mm} \text { gap }\end{array}$ & $\begin{array}{l}\text { unable to } \\
\text { detect due } \\
\text { to label loss }\end{array}$ & ND & $\begin{array}{l}\text { express neurotrophins; } \\
\text { not P0, PMP22 }\end{array}$ & $\begin{array}{l}\text { improved SFI, im- } \\
\text { proved CMAP amp/ } \\
\text { latency }\end{array}$ \\
\hline & $\begin{array}{l}\text { Dezawa } \\
\text { et al., } \\
2001\end{array}$ & Wistar rat & $\begin{array}{l}1-2 \times 10^{7} \\
\text { cells } / \mathrm{ml}\end{array}$ & $\begin{array}{l}\text { in Matrigel, w/in hol- } \\
\text { low fibers; } 15-\mathrm{mm} \\
\text { gap }\end{array}$ & $\geq 3$ wks & MD & MAG+; produced myelin & $\begin{array}{l}\uparrow \text { axonal outgrowth } \\
\text { achieved w/ predif- } \\
\text { ferentiated cells }\end{array}$ \\
\hline & $\begin{array}{l}\text { Zhang et } \\
\text { al., } 2004\end{array}$ & $\begin{array}{l}\text { Sprague- } \\
\text { Dawley rat }\end{array}$ & $10^{7}$ & $\begin{array}{l}\text { microinjected into } \\
\text { crush-injured sciatic } \\
\text { nerve }\end{array}$ & up to 3 wks & ND & $\begin{array}{l}\text { limited expression of } \\
\text { GFAP, S100, p75 }\end{array}$ & ND \\
\hline & $\begin{array}{l}\text { Shimizu } \\
\text { et al., } \\
2007\end{array}$ & $\begin{array}{l}\text { human/ } \\
\text { Wistar rat }\end{array}$ & $\begin{array}{l}1-2 \times \\
10^{6} \text { cells/ } \\
\mathrm{ml}\end{array}$ & $\begin{array}{l}\text { in Matrigel, w/in } \\
\text { transpermeable } \\
\text { tube; } 10-\mathrm{mm} \text { gap }\end{array}$ & $\geq 3$ wks & $\begin{array}{l}<12.6 \pm \\
2.98 \% \text { of } \\
\text { all MAG+ } \\
\text { SCs }\end{array}$ & $\begin{array}{l}\text { MAG+; enveloped re- } \\
\text { generating axons; many } \\
\text { phagocytosed }\end{array}$ & $\begin{array}{l}\text { slight } \uparrow \text { SFI con- } \\
\text { ferred by transdif- } \\
\text { ferentiated cells over } \\
\text { naive }\end{array}$ \\
\hline & $\begin{array}{l}\text { Tohill \& } \\
\text { Terenghi, } \\
2004\end{array}$ & $\begin{array}{l}\text { Sprague- } \\
\text { Dawley rat }\end{array}$ & $\begin{array}{l}8 \times 10^{6} \\
\text { cells } / \mathrm{ml}\end{array}$ & $\begin{array}{l}\text { w/in PHB conduits; } \\
\text { 10-mm gap }\end{array}$ & $\begin{array}{l}\text { up to } 15 \\
\text { days }\end{array}$ & ND & $\begin{array}{l}\text { some differentiated to } \\
\text { S100+ SCs }\end{array}$ & $\uparrow$ outgrowth \\
\hline $\begin{array}{l}\text { C17.2 neonatal } \\
\text { cerebellar } \\
\text { granule cells } \pm \\
\text { overexpression } \\
\text { of GDNF }\end{array}$ & $\begin{array}{l}\text { Heine et } \\
\text { al., } 2004\end{array}$ & $\begin{array}{l}\text { mouse } \\
\text { cell line/ } \\
\text { Sprague- } \\
\text { Dawley rat }\end{array}$ & $\begin{array}{l}5 \times 10^{5} \\
\text { cells }\end{array}$ & $\begin{array}{l}\text { subepineural injec- } \\
\text { tion into chronically } \\
\text { denervated nerve }\end{array}$ & up to 4 mos & $0.5-1 \%$ & $\begin{array}{l}\text { most remained distal } \\
\text { to repair site, very few } \\
\text { GFAP or NF+; mesen- } \\
\text { chymal tumor }\end{array}$ & $\begin{array}{l}\uparrow \text { no. of axons, im- } \\
\text { proved CMAP amp/ } \\
\text { latency }\end{array}$ \\
\hline $\begin{array}{l}\text { hippocampal } \\
\text { E17 neuronal } \\
\text { progentitor cells }\end{array}$ & $\begin{array}{l}\text { Muraka- } \\
\text { mi et al., } \\
2003\end{array}$ & Fischer rat & $10^{5}$ cells & $\begin{array}{l}\text { in collagen gel w/ } \\
\text { in silicone tube; } \\
15-m m \text { gap }\end{array}$ & $\begin{array}{l}\text { up to } 10 \\
\text { wks }\end{array}$ & ND & $\begin{array}{l}\text { some cells positive for } \\
\text { S100/p75 }\end{array}$ & $\begin{array}{l}\text { superior elec- } \\
\text { trophysiological } \\
\text { recovery }\end{array}$ \\
\hline $\begin{array}{l}\text { E11 DRG/ } \\
\text { boundary cap } \\
\text { neural crest } \\
\text { stem cells }\end{array}$ & $\begin{array}{l}\text { Aquino } \\
\text { et al., } \\
2006\end{array}$ & $\begin{array}{l}\text { Rosa } 26 \\
\text { mouse } \\
\text { (lac-Z+)/ } \\
\text { Sprague- } \\
\text { Dawley rat }\end{array}$ & $\begin{array}{l}4 \times 10^{3} \\
\text { cells }\end{array}$ & $\begin{array}{l}\text { intact nerve; } \\
\text { cultured in 12-mm } \\
\text { silicone tube \& } \\
\text { implanted in nerve } \\
\text { gap }\end{array}$ & $\begin{array}{l}\text { up to } 90 \\
\text { days; only } \\
\text { predifferen- } \\
\text { tiated cells } \\
\text { survived }\end{array}$ & ND & $\begin{array}{l}69.7-94.6 \% \text { GFAP+ after } \\
13 \text { \& } 60 \text { days, respec- } \\
\text { tively; MBP+ transplant- } \\
\text { ed cells ensheathed } \\
\text { axons in tube }\end{array}$ & ND \\
\hline \multirow[t]{2}{*}{$\begin{array}{l}\text { neonatal skin/ } \\
\text { neural crestlike } \\
\text { precursors }\end{array}$} & $\begin{array}{l}\text { Marchesi } \\
\text { et al., } \\
2007\end{array}$ & Wistar rat & $10^{6}$ cells & $\begin{array}{l}\text { in PBS in lumen } \\
\text { of collagen guide; } \\
16 \text {-mm gap }\end{array}$ & up to 2 mos & $25-38 \%$ & $\begin{array}{l}4.5 \% \mathrm{~S} 100+, 6.1 \% \\
\text { GFAP+ }\end{array}$ & $\begin{array}{l}\text { improved CMAP, } \\
\text { SFI, no. of myeli- } \\
\text { nated fibers }\end{array}$ \\
\hline & $\begin{array}{l}\text { McKen- } \\
\text { zie et al., } \\
2006\end{array}$ & $\begin{array}{l}\text { rodent or } \\
\text { human/ } \\
\text { shiverer } \\
\text { mouse }\end{array}$ & $\begin{array}{l}1-4 \times \\
10^{5} \text { cells }\end{array}$ & $\begin{array}{l}\text { microinjected distal } \\
\text { to crush injury }\end{array}$ & $\geq 6$ wks & $\sim 6.5 \%$ & $\begin{array}{l}70.4 \% \text { of transplanted } \\
\text { cells MBP+, associated } \\
\text { w/ NFM+ axons }\end{array}$ & $\begin{array}{l}\text { MBP positive myelin } \\
\text { on shiverer axons }\end{array}$ \\
\hline $\begin{array}{l}\text { vibrissal fol- } \\
\text { licles }\end{array}$ & $\begin{array}{l}\text { Amoh et } \\
\text { al., } 2005\end{array}$ & $\begin{array}{l}\text { C57/B6- } \\
\text { GFP/C57/ } \\
\text { B6 mouse }\end{array}$ & ND & $\begin{array}{l}\text { transplanted btwn } \\
\text { severed sciatic/ } \\
\text { tibial nerve stumps }\end{array}$ & $\begin{array}{l}\text { detected } \\
\text { after } 2 \text { mos }\end{array}$ & ND & $\begin{array}{l}\text { GFAP+; envelop } \beta I I I \\
\text { tubulin+ axons }\end{array}$ & $\begin{array}{l}\text { improved SFI, con- } \\
\text { traction of gastroc- } \\
\text { nemius }\end{array}$ \\
\hline $\begin{array}{l}\text { amniotic fluid/ } \\
\text { mesenchymal } \\
\text { stem cells }\end{array}$ & $\begin{array}{l}\text { Muraka- } \\
\text { mi et al., } \\
2003\end{array}$ & $\begin{array}{l}\text { Sprague- } \\
\text { Dawley rat }\end{array}$ & $\begin{array}{l}1.5 \times 10^{4} \\
\text { cells }\end{array}$ & $\begin{array}{l}\text { in fibrin glue around } \\
\text { crushed sciatic } \\
\text { nerve }\end{array}$ & $\begin{array}{l}\text { up to } 10 \\
\text { days, none } \\
\text { at } 4 \text { wks }\end{array}$ & ND & $\begin{array}{l}\text { NT-3 and CNTF+; no } \\
\text { expression of GFAP/ } \\
\text { S100 } \beta\end{array}$ & $\begin{array}{l}\text { motor function } \\
\text { recovery, improved } \\
\text { CMAP }\end{array}$ \\
\hline
\end{tabular}

* CMAP = compound muscle action potential; CNTF = ciliary neurotrophic factor; DRG = dorsal root ganglion; GDNF = glial cell line-derived neurotrophic factor; $\mathrm{MAG}=$ myelin-associated glycoprotein; ND = not described; NF = neurofilament; NFM = neurofilament (medium chain); NT-3 = neurotrophin-3; PHB = poly-3-hydroxybutyrate; P0 = myelin protein 0; PMP22 = peripheral myelin protein 22; SC = Schwann cell; SFI = sciatic functional index; + = positive; $\uparrow$ = increase in. 
cell numbers in these studies. It is admittedly difficult to compare the number of cells delivered in widely different repair paradigms, but it is fair to state that there are likely an ideal number of cells that should be determined for each cell type or repair scenario. Just as too few cells may not translate to a therapeutic effect, delivery of too many cells may also have detrimental results. This was exemplified beautifully by a study using transplanted Schwann cells delivered in 10-mm nerve gap..$^{40}$ When authors used a concentration of $20 \times 10^{6}$ cells $/ \mathrm{ml}$, there was no appreciable increase in axonal regeneration distance. Increasing the concentration to $80 \times 10^{6}$ cells $/ \mathrm{ml}$ proved ideal for regeneration, whereas further increases resulted in slightly poorer regeneration. This same logic likely applies to stem cell transplantation, as they must compete for space and available resources with the cellular milieu of the regenerating nerve. Therefore, optimization strategies should take the number of delivered cells into account. Similarly, the way in which cells are delivered to the injury site has varied between studies, ranging from direct microinjection, ${ }^{36}$ suspension within artificial tubes, ${ }^{10,42,54}$ and seeding within devitalized muscle or nerve grafts. ${ }^{25}$ Although the choice of stem cell delivery method may depend on the type and extent of nerve injury in question, it may be optimized by providing transplanted cells an environment that will favor their survival and integration, such as within structured fibers ${ }^{12}$ or biomatrices. ${ }^{8}$

\section{Differentiation State of Delivered Stem Cells}

Part of the appeal of using precursor or stem cells for supplementing peripheral nerve repair is their capacity for self-renewal, such that it is possible to deliver large numbers of dividing cells to the injury site. ${ }^{65}$ By delivering stem cells into the injured nerve in a naive state, this proliferative capacity is maintained, and it is expected that cells will be prompted by the microenvironment to differentiate into the required cell type. ${ }^{22}$ In vitro studies have demonstrated that neural stem/progenitor cells in coculture with cells from the nervous system will take on a phenotype similar to their partner tissue's origin: dorsal root ganglion cultures will induce a peripheral neuron/ Schwann cell/smooth muscle phenotype, and a cerebellar feeder layer will induce differentiation into CNS neurons. ${ }^{6}$ Nevertheless, incidence of differentiation from naive precursor cells within the peripheral nerve is rather low in many cases. . $^{10,11,18,46}$ Choosing to predifferentiate stem cells toward a desired phenotype prior to delivery into the repair site may be an effective strategy to ensure a more precise and complete therapeutic effect. It may be that cells at later developmental stages (vs embryonic stem cells, for example) possess more mature intrinsic molecular programs to direct them to their target destination. ${ }^{53}$

Because it is well known that mature Schwann cells survive denervation events by secreting autocrine factors such as insulin-like growth factor, neurotrophin-3, and plant-derived growth factor-BB,${ }^{23}$ might an appropriately differentiated stem cell also possess similar machinery for self-preservation and thus be an ideal candidate for supplementing the injured peripheral nerve? We have found that SKPCs, when injected as naive sphere-forming

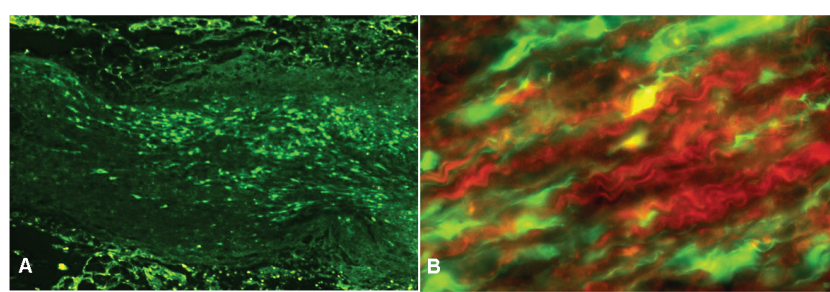

FIG. 1. Fluorescent micrographs of a longitudinal section of sciatic nerve. The SKPCs survive and differentiate within the injured peripheral nerve. Naive GFP-labeled SKPCs (green, A) injected into the transected sciatic nerve demonstrate viability after 8 weeks and integrate along host Schwann cells columns labeled by GFAP (red). The occasional double-labeled cells (yellow) on the merged image (B) are likely SKPCs expressing GFAP, suggesting their in vivo differentiation toward a Schwann cell phenotype. Original magnification $\times 40(A) ; \times 400$ (B).

cells, do differentiate into GFAP-positive Schwann cells in response to cues found in the local environment of the injured peripheral nerve (Fig. 1). However, long-term survival and maintenance of Schwann cell markers is greatly improved by predifferentiating the cells to a Schwann cell phenotype prior to delivery. ${ }^{36}$ On the other hand, others have reported that allowing stem cells to differentiate before delivery accelerates posttransplant cell death, perhaps owing to increased expression of major histocompatibility complex antigens or reduced proliferation rates. ${ }^{59}$ In addition to survival of stem cells, their effect on surrounding tissues may be modified based on their level of differentiation prior to transplantation. For example, when naive adult neural stem cells were injected into a lesioned spinal cord, the resulting aberrant sprouting resulted in profound allodynia. If gliogenesis in these cells was suppressed by prior treatment with neurogenin-2, there was an overall greater functional improvement. ${ }^{19}$ One of the potentially negative consequences of stem cell therapy in any system is the tumorigenic capability of multipotent precursors. Indeed, when the regenerative potential of C17.2 neural stem cells was assessed in 3 different rat sciatic nerve injury models, there was a high incidence of tumor formation by the transplanted cells..$^{18,24}$

\section{Improving Survival of Transplanted Stem Cells}

Whether due to technical challenges or oversight, it is an unfortunate reality that survival of stem cells delivered to nerve injury sites is reported only infrequently. When quantified, precursor cells have shown between 0.5 and $38 \%$ survival, depending on evaluation time point and cell type. . $^{18,34,36,54}$ In our laboratory, we have also seen differences in survival based on nerve injury model and differentiation state of the cells at transplantation (unpublished observations). For example, when we delivered naive SKPCs into an acutely injured nerve, survival after 2 weeks was $\sim 10.5 \%$, whereas when delivered into a nerve that had been previously chronically denervated, the number of detected SKPCs decreased to $5.8 \%$. Seeing that $78 \%$ of the surviving stem cells in the chronic model had differentiated into GFAP-positive Schwann cells, we next used predifferentiated (Schwann cell-like) SKPCs and found that we could increase survival to $\geq 8 \%$. Without quantification of survival in stem cell transplantation 


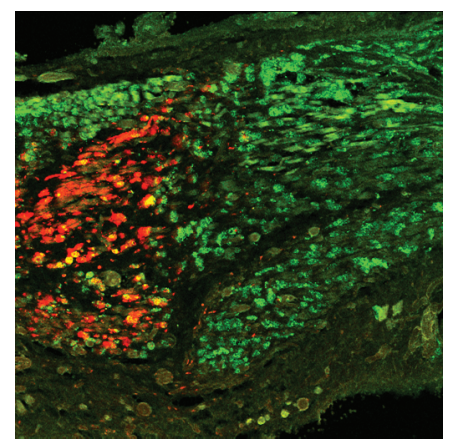

FIG. 2. Confocal image. The SKPC-Schwann cells are not immediately cleared by host immune system. Eight weeks following injection into an initially decellularized (by repetitive freeze-thawing) nerve graft bridging a 12-mm defect created in the rodent sciatic nerve, SKPCSchwann cells (red), and ED-1-positive macrophages (green) are spatially segregated within the longitudinal extent of the nerve graft. The finding that there is very little colabeling of SKPC-Schwann cells with ED-1 positive macrophages suggests that transplanted cells are not phagocytosed in any large quantity within the host nerve. Original magnification $\times 400$.

experiments, it is difficult to determine whether they are being retained long enough and in enough numbers to confer a sufficient benefit to regeneration. The danger of exogenous cell therapy is of course cell death caused by immune system attack. ${ }^{59}$ Although some authors have reported considerable phagocytosis of transplanted stem cells, ${ }^{54,59}$ this may be due to species/strain mismatching of donor and recipient, as many others have not observed this trend. In fact, we have observed a highly interesting pattern of surviving transplanted SKPCs that are spatially separate from phagocytic ED-1-positive macrophages (Fig. 2). The question of survival is mechanistically interesting, as improvement in regeneration outcomes has been also been observed in the absence of detection of transplanted cells. ${ }^{46}$

If a minimum survival time of stem cells is indeed required to observe a therapeutic effect, strategies should be devised to increase the amount of time cells remain in grafted regions. Survival and effectiveness of transplanted cells can be improved by ex vivo genetic manipulation or concomitant delivery of protective agents or trophic factors. Pan and colleagues ${ }^{45}$ found that administration of granulocyte-colony stimulating factor to animals receiving transplants of amniotic fluid mesenchymal stem cells not only improved survival of transplanted cells but also augmented nerve regeneration over that of a primarily cell-based approach. Additionally, differences in the material in which stem cells are delivered have demonstrated varying capacities to support long-term cell survival. ${ }^{8,47}$ Finally, immunosuppressive regimens, especially in the light of interspecific transplants may protect stem cells from premature clearance from the nerve injury site. ${ }^{47}$

Influence of Final Stem Cell Phenotype on Regenerative Success

As with survival, differentiation of stem cells within the injury site has demonstrated a mixed correlation to therapeutic effect. Some studies have demonstrated a need for differentiation to glial phenotype to observe adequate regeneration of neural tissue, and others have shown improvement with little to no differentiation of stem cells at the assessment end point. ${ }^{60}$ Furthermore, the glial differentiation of transplanted stem cells within the injured peripheral nerve has tended to vary between studies, even within the same cell type. Keilhoff and colleagues ${ }^{26}$ could not detect Schwann cell differentiation of transplanted marrow stromal cells if delivered in a naive state, whereas Zhang et al. ${ }^{75}$ observed at least limited expression of S100, p75, and GFAP markers in similarly obtained cells. In this case, the difference in repair paradigms (devitalized muscle graft versus crush injured nerve) may explain the disparity in the ability of these cells to differentiate, outlining the need for careful consideration of the method of delivering stem cells to the injury site. In the cases in which adequate regeneration and improvement of outcomes occurs without Schwann cell differentiation of transplanted precursors, it may be that the cells are supporting axonal growth by additional mechanisms such as the production of cytokines or harnessing the inflammatory response. ${ }^{42}$ Although C17.2 neural stem cells show little differentiation into a Schwann cell phenotype in the chronically denervated peripheral nerve, their secretion of various matrix metalloproteinases, capable of breaking down growth-inhibiting chondroitin sulfate proteoglycans, likely underlies their ability to elicit superior regeneration. ${ }^{8}$ Similarly, unpublished observations from our laboratory have shown that impure cultures of SKPCs at an early stage of Schwann cell differentiation secrete detectable levels of a number of neurotrophins despite lacking typical Schwann cell morphology or histological markers. Therefore the following question remains: must stem cells fully adopt a stereotypical Schwann cell phenotype to be successful adjuncts to nerve repair? Careful examination of ultimate cell fate with correlation to functional outcome is strongly recommended for future precursor transplant studies and will be required to fully answer this question for each cell type and repair strategy. It may be that, at least for some precursor cell types, there is a minimum level of differentiation to $\mathrm{S} 100 \beta / \mathrm{MBP} /$ GFAP-positive Schwann cells that is required for acceptable regeneration outcomes. If this is the case, effectiveness of precursor transplantation could be improved using technology that exists to directly alter the regenerative microenvironment by continuous delivery of neuregulins, forskolin, or other differentiation-promoting factors. ${ }^{35}$

\section{Methods for Tracking Fate of Transplanted Stem Cells}

Given the evidence presented above, it is apparent that studies exploring stem cell transplantation for peripheral nerve repair should give careful thought on strategies to track the fate of transplanted cells over time. There is often little importance placed on prelabeling cells prior to delivery into the injured nerve, and as such authors cannot comment on the mechanism of any advantage conferred by cell therapy. Others have used labeling techniques that are not sufficiently robust or long-lasting to be detected at the study end points. ${ }^{10}$ Chemical markers such as bisbenzimide and PKH26 have been used to label Schwann cells 


\section{S. Walsh and R. Midha}

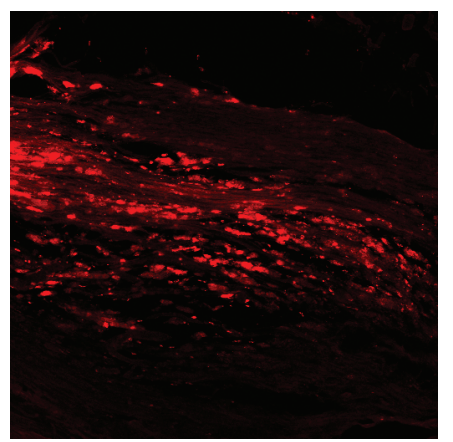

FIG. 3. Confocal image. The CM-Dil is reliable method for long-term cell fate tracking within the peripheral nerve. The SKPC-Schwann cells prelabeled for 20 minutes in $2 \mu \mathrm{M}$ CM-Dil retain bright labeling (red) for $\geq 8$ weeks following transplantation into an acellular nerve graft bridging a gap in the rodent sciatic nerve, allowing for quantification without using additional dye techniques. Original magnification $\times 200$.

delivered to peripheral nerve injuries, but their usefulness is limited to the short term and may in fact affect the viability and phenotype of transplanted cells. ${ }^{39}$ Genetic labeling with either lac $Z$ or fluorescent proteins such as GFP is increasingly popular and appears to be a relatively long-lasting method that is not deleterious to transduced cells. ${ }^{12,40}$ We have used the lipophilic carbocyanine derivative CellTracker CM-DiI (Molecular Probes) to reliably label SKPCs within a variety of nerve injury models with no dilution or loss of signal for $\geq 10$ weeks following transplantation (Fig. 3). These dyes have the advantage of being technically simple to use, rapid, and resistant to leakage to nearby cells. Emerging technologies such as quantum dots offer an exciting alternative to traditional cell labeling methods. These nanoparticles are available in a wide range of photostable colors and are resistant to chemical and metabolic degradation, making them ideal for use in long-term fate tracking of transplanted stem cells. ${ }^{41}$

\section{Conclusions}

Animal studies have demonstrated that transplantation of stem and precursor cells has the potential to serve as an adjunct therapy to common practices of surgical nerve repair. Although the application of cell-based strategies in a clinical setting is promising, optimization of cell delivery and careful investigation of the fate of transplanted cells is required to guarantee the safety and maximum efficacy of these therapies. As discussed in this review, it will be important to determine the ideal number and method of cell delivery, and elucidate the extent of transplant cell survival and differentiation that is required to elicit a therapeutic effect. Future studies should place emphasis on using reliable labeling methods to track the long-term fate of transplanted cell. Finally, while many cell types have been investigated for their potential use in cell replacement therapy, few studies have directly compared the utility of different stem cells in augmenting peripheral nerve repair. We believe that cells that are easily isolated from autologous sources such as the skin and that can survive and differentiate to a glial phenotype within the milieu of the injured nerve provide the most promise.

\section{Disclosure}

The Canadian Institute of Health Research (MOP 82726) provided funding for this work.

\section{References}

1. Amoh Y, Li L, Campillo R, Kawahara K, et al: Implanted hair follicle stem cells form Schwann cells that support repair of severed peripheral nerves. Proc Natl Acad Sci U S A 102:17734-17738, 2005

2. Aquino JB, Hjerling-Leffler J, Koltzenburg M, et al: In vitro and in vivo differentiation of boundary cap neural crest stem cells into mature Schwann cells. Exp Neurol 198:438-449, 2006

3. Archibald SJ, Krarup C, Shefner J, et al: A collagen-based nerve guide conduit for peripheral nerve repair: an electrophysiological study of nerve regeneration in rodents and nonhuman primates. J Comp Neurol 306:685-696, 1991

4. Azizi SA, Stokes D, Augelli BJ, et al: Engraftment and migration of human bone marrow stromal cells implanted in the brains of albino rats-similarities to astrocyte grafts. Proc Natl Acad Sci U S A 95:3908-3913, 1998

5. Bellamkonda RV: Peripheral nerve regeneration: an opinion on channels, scaffolds and anisotropy. Biomaterials 27:35153518,2006

6. Brannvall K, Corell M, Forsberg-Nilsson K, et al: Environmental cues from CNS, PNS, and ENS cells regulate CNS progenitor differentiation. Neuroreport 19:1283-1289, 2008

7. Bungner OV: Uber die Degenerations und Regenerationsvorgange am Nerven nach Verletzungen. Beitr Pathol Anat 10:321-387, 1891

8. Cao F, Sadrzadeh Rafie AH, Abilez OJ, et al: In vivo imaging and evaluation of different biomatrices for improvement of stem cell survival. J Tissue Eng Regen Med 1:465-468, 2007

9. Carroll SL, Miller ML, Frohnert PW, et al: Expression of neuregulins and their putative receptors, ErbB2 and ErbB3, is induced during Wallerian degeneration. J Neurosci 17:16421659,1997

10. Chen CJ, Ou YC, Liao SL, et al: Transplantation of bone marrow stromal cells for peripheral nerve repair. Exp Neurol 204:443-453, 2007

11. Cuevas P, Carceller F, Garcia-Gomez I, et al: Bone marrow stromal cell implantation for peripheral nerve repair. Neurol Res 26:230-232, 2004

12. Dezawa M, Takahashi I, Esaki M, et al: Sciatic nerve regeneration in rats induced by transplantation of in vitro differentiated bone-marrow stromal cells. Eur J Neurosci 14:17711776,2001

13. Fernandes KJ, McKenzie IA, Mill P, et al: A dermal niche for multipotent adult skin-derived precursor cells. Nat Cell Biol 6:1082-1093, 2004

14. Fu SY, Gordon T: The cellular and molecular basis of peripheral nerve regeneration. Mol Neurobiol 14:67-116, 1997

15. Fu SY, Gordon T: Contributing factors to poor functional recovery after delayed nerve repair: prolonged denervation. J Neurosci 15:3886-3895, 1995

16. Guenard V, Kleitman N, Morrissey TK, et al: Syngeneic Schwann cells derived from adult nerves seeded in semipermeable guidance channels enhance peripheral nerve regeneration. J Neurosci 12:3310-3320, 1992

17. Guest JD, Rao A, Olson L, et al: The ability of human Schwann cell grafts to promote regeneration in the transected nude rat spinal cord. Exp Neurol 148:502-522, 1997

18. Heine W, Conant K, Griffin JW, et al: Transplanted neural stem 
cells promote axonal regeneration through chronically denervated peripheral nerves. Exp Neurol 189:231-240, 2004

19. Hofstetter CP, Holmstrom NA, Lilja JA, et al: Allodynia limits the usefulness of intraspinal neural stem cell grafts; directed differentiation improves outcome. Nat Neurosci 8:346-353, 2005

20. Hu J, Zhu QT, Liu XL, et al: Repair of extended peripheral nerve lesions in rhesus monkeys using acellular allogenic nerve grafts implanted with autologous mesenchymal stem cells. Exp Neurol 204:658-666, 2007

21. Humphreys DB, Novak CB, Mackinnon SE: Patient outcome after common peroneal nerve decompression. J Neurosurg 107:314-318, 2007

22. Jan YN, Jan LY: Asymmetric cell division. Nature 392:775778,1998

23. Jessen KR, Mirsky R: Why do Schwann cells survive in the absence of axons? Ann N Y Acad Sci 883:109-115, 1999

24. Johnson TS, O'Neill AC, Motarjem PM, et al: Tumor Formation Following Murine Neural Precursor Cell Transplantation in a Rat Peripheral Nerve Injury Model. J Reconstr Microsurg 24: 545-550, 2008

25. Keilhoff G, Goihl A, Stang F, et al: Peripheral nerve tissue engineering: autologous Schwann cells vs. transdifferentiated mesenchymal stem cells. Tissue Eng 12:1451-1465, 2006

26. Keilhoff G, Stang F, Goihl A, et al: Transdifferentiated mesenchymal stem cells as alternative therapy in supporting nerve regeneration and myelination. Cell Mol Neurobiol 26:12351252,2006

27. Kelsey JL, Praemer A, Nelson L, et al: Upper extremity disorders. Frequency, impact, and cost. New York: Churchill Livingstone Inc., 1997

28. Kemp SW, Walsh SK, Zochodne DW, et al: A novel method for establishing daily in vivo concentration gradients of soluble nerve growth factor (NGF). J Neurosci Methods 165:83-88, 2007

29. Kim DH, Connolly SE, Kline DG, et al: Labeled schwann cell transplants versus sural nerve grafts in nerve repair. J Neurosurg 80:254-260, 1994

30. Kingham PJ, Kalbermatten DF, Mahay D, et al: Adiposederived stem cells differentiate into a Schwann cell phenotype and promote neurite outgrowth in vitro. Exp Neurol 207:267-274, 2007

31. Kline DG, Hudson AR: Nerve injuries: Operative Results from Major Nerve Injuries, Entrapments, and Tumors. Philadelphia: WB Saunders Co, 1995

32. Li H, Terenchi G, Hall SM: Effects of delayed re-innervation on the expression of c-erb receptors by chronically denervated rat Schwann cells in vivo. Glia 20:333-347, 1997

33. Mahanthappa NK, Anton ES, Matthew WD: Glial growth factor 2, a soluble neuregulin, directly increases Schwann cell motility and indirectly pormotes neurite outgrowth. J Neurosci 16:4673-4683, 1996

34. Marchesi C, Pluderi M, Colleoni F, et al: Skin-derived stem cells transplanted into resorbable guides provide functional nerve regeneration after sciatic nerve resection. Glia 55:425438, 2007

35. McDonald DS, Zochodne DW: An injectable nerve regeneration chamber for studies of unstable soluble growth factors. J Neurosci Methods 122:171-178, 2003

36. McKenzie IA, Biernaskie J, Toma JG, et al: Skin-derived precursors generate myelinating Schwann cells for the injured and dysmyelinated nervous system. J Neurosci 26:66516660,2006

37. Midha R, Kline DG: Evaluation of the neuroma in continuity, in Omer GE, Spinner M, Van Beek AL (eds): Management of Peripheral Nerve Problems. Philadelphia: WB Saunders Co, 1998, pp 319-327

38. Mirsky R, Jessen KR: The neurobiology of Schwann cells. Brain Pathol 9:293-311, 1999
39. Mosahebi A, Woodward B, Green C, et al: Long-term effect of vital labelling on mixed Schwann cell cultures. Histochem J 32:337-343, 2000

40. Mosahebi A, Woodward B, Wiberg M, et al: Retroviral labeling of Schwann cells: in vitro characterization and in vivo transplantation to improve peripheral nerve regeneration. Glia 34:8-17, 2001

41. Muller-Borer BJ, Collins MC, Gunst PR, et al: Quantum dot labeling of mesenchymal stem cells. J Nanobiotechnology 5:9, 2007

42. Murakami T, Fujimoto Y, Yasunaga Y, et al: Transplanted neuronal progenitor cells in a peripheral nerve gap promote nerve repair. Brain Res 974:17-24, 2003

43. Nichols CM, Brenner MJ, Fox IK, et al: Effects of motor versus sensory nerve grafts on peripheral nerve regeneration. Exp Neurol 190:347-355, 2004

44. Noble J, Munro CA, Prasad VSSV, et al: Analysis of upper and lower extremity peripheral nerve injuries in a population of patients with multiple injuries. J Trauma 45:116-122, 1998

45. Pan HC, Chen CJ, Cheng FC, et al: Combination of G-CSF administration and human amniotic fluid mesenchymal stem cell transplantation promotes peripheral nerve regeneration. Neurochem Res [epub ahead of print], 2008

46. Pan HC, Cheng FC, Chen CJ, et al: Post-injury regeneration in rat sciatic nerve facilitated by neurotrophic factors secreted by amniotic fluid mesenchymal stem cells. J Clin Neurosci 14:1089-1098, 2007

47. Parr AM, Kulbatski I, Wang XH, et al: Fate of transplanted adult neural stem/progenitor cells and bone marrow-derived mesenchymal stromal cells in the injured adult rat spinal cord and impact on functional recovery. Surg Neurol 70:600-607, 2008

48. Pearse DD, Pereira FC, Marcillo AE, et al: cAMP and Schwann cells promote axonal growth and functional recovery after spinal cord injury. Nat Med 10:610-616, 2004

49. Pellegrino RG, Spencer PS: Schwann cell mitosis in response to regenerating peripheral axons in vivo. Brain Res 341:1625,1985

50. Ramon y Cajal S: Degeneration and Regeneration of the Nervous System. New York: Oxford University Press, 1928, pp 66-69

51. Samii A, Carvalho GA, Samii M: Brachial plexus injury: factors affecting functional outcome in spinal accessory nerve transfer for the restoration of elbow flexion. J Neurosurg 98:307-312, 2003

52. Scherer SS, Salzer JL: Axon-Schwann cell interactions during peripheral nerve degeneration and regeneration, in Jessen KR, Richardson WD (eds): Glial Cell Development. Oxford, UK: Bios Scientific, 1996, pp 169-196

53. Sekiya T, Kojima K, Matsumoto M, et al: Replacement of diseased auditory neurons by cell transplantation. Front Biosci 13:2165-2176, 2008

54. Shimizu S, Kitada M, Ishikawa H, et al: Peripheral nerve regeneration by the in vitro differentiated-human bone marrow stromal cells with Schwann cell property. Biochem Biophys Res Commun 359:915-920, 2007

55. Sieber-Blum M, Grim M, Hu YF, et al: Pluripotent neural crest stem cells in the adult hair follicle. Dev Dyn 231:258-269, 2004

56. Sunderland S: Nerve Injuries and Their Repair. A Critical Appraisal. Melbourne: Churchill Livingstone, 1991

57. Sunderland S: Nerve and Nerve Injuries, 2 ed. Edinburgh: Churchill-Livingstone, 1978

58. Sunderland S: Rate of regeneration in human peripheral nerves. Arch Neurol Psychiatry 58:251-295, 1947

59. Swijnenburg RJ, Schrepfer S, Cao F, et al: In vivo imaging of embryonic stem cells reveals patterns of survival and rejection following transplantation. Stem Cells Dev 17:1023-1029, 2008 


\section{S. Walsh and R. Midha}

60. Sykova E, Jendelova P: Migration, fate and in vivo imaging of adult stem cells in the CNS. Cell Death Differ 14:1336-1342, 2007

61. Takami T, Oudega M, Bates ML, et al: Schwann cell but not olfactory ensheathing glia transplants improve hindlimb locomotor performance in the moderately contused adult rat thoracic spinal cord. J Neurosci 22:6670-6681, 2002

62. Taniuchi M, Clark HB, Schweitzer JB, et al: Expression of nerve growth factor receptors by Schwann cells of axotomized peripheral nerve: ultrastructural location, suppression by axonal contact, and binding properties. J Neurosci 8:664-681, 1988

63. Tofaris GK, Patterson PH, Jessen KR, et al: Denervated Schwann cells attract macrophages by secretion of leukemia inhibitory factor (LIF) and monocyte chemoattractant protein-1 in a process regulated by interleukin- 6 and LIF. J Neurosci 22:6696-6703, 2002

64. Tohill M, Mantovani C, Wiberg M, et al: Rat bone marrow mesenchymal stem cells express glial markers and stimulate nerve regeneration. Neurosci Lett 362:200-203, 2004

65. Tohill M, Terenghi G: Stem-cell plasticity and therapy for injuries of the peripheral nervous system. Biotechnol Appl Biochem 40:17-24, 2004

66. Toma JG, Akhavan M, Fernandes KJ, et al: Isolation of multipotent adult stem cells from the dermis of mammalian skin. Nat Cell Biol 3:778-784, 2001

67. Toma JG, McKenzie IA, Bagli D, et al: Isolation and characterization of multipotent skin-derived precursors from human skin. Stem Cells 23:727-737, 2005

68. Unsicker K, Strelau J: Functions of transforming growth factor-beta isoforms in the nervous system. Cues based on localization and experimental in vitro and in vivo evidence. Eur J Biochem 267:6972-6975, 2000
69. Vitry S, Bertrand JY, Cumano A, et al: Primordial hematopoietic stem cells generate microglia but not myelin-forming cells in a neural environment. J Neurosci 23:10724-10731, 2003

70. Wang D, Liu XL, Zhu JK, et al: Bridging small-gap peripheral nerve defects using acellular nerve allograft implanted with autologous bone marrow stromal cells in primates. Brain Res 1188:44-53, 2008

71. Weber RA, Breidenbach WC, Brown RE, et al: A randomized prospective study of polyglycolic acid conduits for digital nerve reconstruction in humans. Plast Reconstr Surg 106:1036-1045, 2000

72. Weinberg HJ, Spencer PS: The fate of Schwann cells isolated from axonal contact. J Neurocytol 7:555-569, 1978

73. Xu Y, Liu L, Li Y, et al: Myelin-forming ability of Schwann cell-like cells induced from rat adipose-derived stem cells in vitro. Brain Res [epub ahead of print], 2008

74. You S, Petrov T, Chung PH, et al: The expression of the low affinity nerve growth factor receptor in long-term denervated Schwann cells. Glia 20:87-100, 1997

75. Zhang P, He X, Liu K, et al: Bone marrow stromal cells differentiated into functional Schwann cells in injured rats sciatic nerve. Artif Cells Blood Substit Immobil Biotechnol 32:509-518, 2004

Manuscript submitted October 14, 2008.

Accepted November 14, 2008.

Address correspondence to: Rajiv Midha, M.D.,M.Sc.,F.R.C.S.C., Division of Neurosurgery, Department of Clinical Neurosciences, University of Calgary, Room 1195, 1403 29th Street NW, Calgary, Alberta, Canada T2N 2T9. email: rajmidha@ucalgary.ca. 